\title{
SOCIAL NETWORKS AS A MEDIA COMMUNICATION CHANNEL
}

\author{
Grigory Vakku $^{1 *}$, Anna Sasim ${ }^{2}$, Svetlana Stepanova ${ }^{3}$ \\ ${ }^{1}$ Candidate of philological Sciences, associate Professor, Moscow state University of Humanities \\ and Economics, Russia, vakku2006@rambler.ru, ORCID 0000-0001-7676-8962; \\ SPIN-код: 3886-4740; AuthorID: 284494 \\ ${ }^{2}$ Candidate of philosophy, associate Professor of the Department of advertising and public \\ relations, Fgbvou VO "Academy of civil protection EMERCOM, Russia, anna-sasim@mail.ru, \\ SPIN-code: 4082-4599, AuthorID: 703082 \\ ${ }^{3}$ Candidate of philosophy, associate Professor, «Chuvash state pedagogical University I. Y. \\ Yakovleva», Russia, clers@mail.ru, SPIN-код: 9615-5690, AuthorID: 443187 \\ ${ }^{*}$ Corresponding Author
}

\begin{abstract}
The demand for social networks is increasing every year, and the sites themselves are constantly developing, trying to incorporate into their functionality all the most necessary for users. The audience of social networks in Russia in 2020 reached 70 million people - this is about $48 \%$ of the total population of the country.

The purpose of this article is to study the promotion of the media in various social networks and identify specific features and techniques in establishing communication processes.

In accordance with this goal, we have to solve a number of tasks: to study and identify the specifics of social networks as an Internet platform; to study what formats are used by modern Russian-language media of various topics in social networks; analyze their choice of the main platform for promoting content.

The most popular internet platforms today are social networks and instant messengers. It is here that users spend the majority of their time on the Internet; here any product gets access to a huge number of tools that help it reach its target audience. Unsurprisingly, the media hasn't left social media behind. Today the overwhelming majority of print and Internet publications, TV channels and radio stations have so-called representation in social networks.

Research methods. This article uses: a method for analyzing the works of foreign and domestic media researchers, a method for observing evolutionary changes in media activities on all modern technological platforms and a monitoring method for tracking the formation of communication.

Methodological basis of the work. During the existence of social networks, their functionality has been devoted to many works of modern scientists, which we took into account when writing this work. So, social networks as a mass media resource are studied by such researchers as: A. A. Gradyushko. The functional features of social networks have been studied by D. A. Shvetsov, E. I. Makarenko and others.
\end{abstract}

Keywords: social networks, online edition, promotion, communication, media format, media content, media platform, editorial office, channel.

\section{INTRODUCTION}

Today, scientists are paying close attention to the study of problems related to the means of communication, with the Internet, as well as its component - social networks. Let us turn to the essence of the concept of "mass communication". Mass communication is the process of disseminating information (knowledge, 
spiritual values, moral and legal norms, etc.) using technical means (press, radio, television, computers, etc.) to numerically large, dispersed audiences (Frolova, 2014). Social networks play an important role in solving this problem. They are designed to create and organize communication between people on the global Internet.

In our study, we accept the following position that social networks are "a fundamentally new area of construction, reproduction and organization of social relations" (Ushkin, 2015), "provide ample opportunities for the implementation of various sociocultural practices, the basis of which is communication" (Grimov, 2014). In addition, social networks contribute to the implementation of the basic social needs of their users (Gubanov, Novikov, 2009).

To disclose the questions raised, we accept social networks as mass media, which are a universal public platform. At the same time, they provide an opportunity for informal communication and for official speeches. Considering a social network as a means of communication, we highlight the following main functions: communicative, image, commercial, social, informational, and entertainment.

\section{OPINIONS AND DISCUSSION}

The variety of the genre nature of a social network is determined by the properties, features that are characteristic of all social networks and Internet communication. Let's highlight three basic characteristic features of speech genres functioning in social networks:

1. Creolized character. The discourse of a social network as, hypertext, and as the main characteristics of the service can be called the creolization of the text, in which the center of communicative activity is the image (photo) with comments.

2. Application of hashtags. The hashtag on the network denotes the topic of a post or comment. The hashtag needs to become a new form of self-expression. Therefore, users should consider the question of how to create an original hashtag. The generally accepted rule for using hashtags is to choose terms related to the subject of the message. Moreover, they are added to one message in a small amount (Atyagina, 2014).

3. Interactivity. By exposing content, the author of the account addresses it to a part of the audience that he wants to see among his subscribers, along with potential ones.

As a means of mass communication, social networks imply synchronicity, this is the possibility of almost simultaneously creating a message and responding to it. Now social networks act as the interaction of elements of interpersonal, group and mass communication. The main role is self-identification, as well as virtual socialization of the subject of communication.

Thus, social networks are becoming an increasingly popular application every year. Their primary role - to unite people and give them a new platform for communication - they fulfilled and became part of mass communication.

With the development of new technologies, networks have penetrated into all areas of human activity. This is facilitated by smartphones, gadgets and the Internet. Thanks to social networks, users quickly receive information and immediately take part in the discussed text. It has been studied that each social network has its own characteristics and characteristics. The following signs are common: requirements of behavior in a group or on a page; the structure of users is of different ages and motley; a large number of subscribers (these are users who subscribed to this page or joined this group); community news "wall"; profile data that contains imprint or other information.

Generally, the audience of social media is more active than the audience of traditional media. Therefore, the penetration of the media into social networks gives the media access to an active, younger audience. The result is active communication. It manifests itself in the comments, where readers express their opinions. This is a great form for organizing feedback. Other forms also contribute to this. For example, poll, questionnaire, etc. (Kornysheva, 2020).

Today, the leaders of social media networks are Facebook, Instagram, Vkontakte, YouTube and Odnoklassniki. To post news on social networks, you need to know the specifics of each. Since the way of presenting news in each network is different. They also differ in their audience (Official website "Mediakop").

Social media statistics in Russia (tab.1) for December 2020 are as follows. 
Table 1.

\section{Social media statistics in Russia}

\begin{tabular}{|c|c|c|c|c|c|}
\hline & Instagram & $\begin{array}{c}\text { In contact } \\
\text { with }\end{array}$ & Facebook & Classmates & YouTube \\
\hline Monthly Reach & 34557 & 40848 & 22521 & 23130 & 44228 \\
\hline $\begin{array}{c}\text { Average Daily } \\
\text { Reach }\end{array}$ & 16586 & 23110 & 5243 & 8620 & 18774 \\
\hline Avg.min.per.day & 23 minutes & 33 minutes & 8 minutes & 18 minutes & 49 minutes \\
\hline
\end{tabular}

Based on the study of various types of Internet resources, research revealed the following patterns. For example, a radio content plan for publications, channels and TV communities in social networks. To the first type of posts that go according to the editorial plan of the media. They correspond to publications in print and on the Internet. To the second type of publication, created specifically for users of social networks. In most cases, they are entertaining and are a means of engaging users in communication with the media on the pages of a social network. Russian media are now moving away from conventional social media content with simple images and hyperlinks. We started using modern promotion tools. In addition, some social networks have different content requirements. As mentioned above, this is due to the use of new promotion tools. For example, at the end of 2019 Instagram has released an updated recommendation algorithm. Today, there is no need to leave popular hashtags in order to get the journalist's material into the "top" (Official website "How the media work with social networks: a detailed guide to promotion-2019"). Since there is no general "top". Today each user will see only his own section "Recommendations". It is constantly being updated. Content is selected based on two parameters. The first parameter is "High quality", that is, the speed and number of entered values. The second parameter is "Freshness". However, it should be noted that for Instagram algorithms the visual part is no longer the main one. Algorithms aim at combining words that appear in posts. For example, if the text contains the words "sport" and "festival", then the post falls into the category "Sports festivals". The individual posts on Instagram themselves are not very important today, since the system makes decisions at the level of the whole account. Not only posts, but also stories, shopping posts and IGTV videos were included in the "Algorithms-Recommendations" (Butyrina, 2019).

At present, one can see a tendency towards competition between the official media web page and the group of the same media on social networks. It should be noted that the competent maintenance of the page (group) of media in social networks has led to direct competition between the official Internet page of the media and the page (group) of the same media in social networks. "A certain competition for Internet media sites is made by communities in social networks dedicated to the news of this or that city. Publics have become both an example of modern Internet culture and a source of socially significant information, the popularity of which sometimes exceeds the attendance of classic news sites. There are similar social communities in most cities, and they are popular primarily among the youth audience" (Gradyushko, 2012).

The traffic of most online publications comes from social media. Therefore, their maintenance is no less important than high-quality website content. How to handle Twitter, Facebook and Vkontakte? The head of Meduza, Galina Timchenko, highlights the following positions: 1. Each social network needs an individual approach; 2. To study the features of each social network; 3. Perceive social networks as a separate product, and not as a site representation; 4 . Check if you are doing everything right; 5 . Observe shares in social networks - do not give advantages to one; 6 . Stop fighting for the main page - social networks have reduced its importance; 7 . Thoroughly plan the site design - social networks reduce the depth of view; 8 . Do not trust technical departments with footers - the algorithm suggests the reader to read the same; 9 . If you hire SMM-specialists, they should be in the editorial office, and not outsource; 10.Know the audience of each social network; 11 . Correctly measure the success of your social networks; 12 . Regulate communication in social networks (Official website «Timchenko Galina Promotion of media in social networks»).

With the help of social networks, the media solve many problems. If you need to quickly conduct a social survey, convey relevant information to the target audience, for example. Nowadays, almost all print, audio and media channels have their own official communities on social networks. Image makers also actively use social networks to "promote" their interests, when it is necessary to create a media image of a region or city, since the investment attractiveness of a city and its competitiveness among other cities largely depend on 
this (Morozova, 2010). The site http://marketing.academic.ru/ gives the following interpretation of this concept. "Promotion is the use of a variety of marketing methods and marketing communication tools that allow you to successfully bring a product to the market, stimulate sales and create loyal company (brand) buyers" (Official website "Academician"). The site http://www.kakprosto.ru/ contains an alternative version of the concept of "Promotion": "Promotion is a list of measures aimed at increasing the efficiency of sales" (Official website "How simple ru."). The vital activity of any media begins with registration with the appropriate authority. Further, the development process begins, and in parallel, progress. What is "promotion". The media can solve these problems with the help of social networks, especially in the period of formation, since they are accessible, easy to use, are distinguished by their efficiency in posting information, as a result, it is possible to get instant feedback.

It has become a fashionable phenomenon that the media often provide links to the statements of officials and leaders of different ranks of opinion, which are published on social networks. Here we will see the transformation of the status of networks. If earlier they were perceived as an entertainment resource, now they are means of influence and influence. "The presence on social networks has recently become the most important characteristic of online media. It manifests itself as the presence of popular accounts of the edition in the most popular social media (VKontakte, Instagram, etc.), and the presence of special buttons under each publication for adding content to social networks"(Gradyushko, 2012).

Usually, an incomplete publication is posted on a page on a social network, sometimes only the title of the text. This can be seen in publications, in groups of the social media network, as well as in the materials of news agencies.

So instead of a headline, they put a lead to attract the attention of the reader. Then, the photo related to the publication is posted. Under the layout, a link to the material in the original source is provided, so that the reader goes to the media site. This format has been slightly modified in Instagram applications, where photography is the main informative material. The function of the title and lead is performed by hashtags.

In addition, the hypertext capabilities of social networks are actively used, which send the consumer of information to the primary source page. The circuit also works in the opposite direction. That is, the technical capabilities of any media site make it possible to repost (copy a record) to your personal page on the network. Thus, it can be argued that a journalistic work embedded in the web space is characterized by hypertextuality.

It connects the text with other information sources, which allows us to talk about the integration of media with social media (Kuzmina, 2011).

Not all news from the home page of a personal media site is posted on social networks. It contains the most relevant ones that arouse the interest of the target audience of the publication.

The main quality when creating media content on the Internet is efficiency. The journalist quickly uploads content from any point where there is access to the global network. In addition, the web space allows you to quickly upload material that is characterized by clarity, and also makes it possible to update or edit the publication.

Usually, materials posted on social networks are published daily with a personal media site, which confirms the relevance and efficiency of these materials (Gazizova, 2016).

In technical terms, social networks allow you to post under the main text not only illustrations, but also video materials, current reports, your own professional and amateur filming. Transmission of messages in different sign systems: be graphic, verbal, sound, photo, video or animated, confirms the high potential of multimedia in social networks. Sometimes population survey scales and questionnaires are attached to some materials on social networks. This interactive social media environment allows users to comment on photos, text and videos, and to enter into dialogue between readers, contact the author and get a quick response. Sometimes readers' discussion based on commentary unfolds underneath some materials. Arguably the Internet and social networks have brought new modern and necessary qualities to journalism, providing users and readers with new media content.

The next quality inherent in the Internet and social networks is measurability. The network owns tools that allow you to quickly assess how popular a particular publication is. Elements of media marketing are automatically built into the system itself. This phenomenon is visible on the official pages in social networks of any media. Media popularity shows the number of subscribers and daily traffic users. The most recent data is available only to page administrators. "Social networks are becoming new effective channels of communication with the audience for the media. Sites of Internet editions can significantly increase their 
audience at the expense of users of social networks thanks to specially prepared texts for them,"says AA researcher Gradyushko (Vakku, Klimkina, 2020).

\section{CONCLUSION}

So, publications that are posted on the Internet by media editors have the following properties: hypertextuality, multimedia and interactivity. Social media, like the media, is personalized. They are responsive, measurable, illustrative and flexible. All this suggests that the transformed product is beginning to take on the character of a media text, the existence of which is always supported by the Internet environment of a social network. Today groups and communities on social networks are popular, along with official media pages. The integration of the official electronic media pages and official media pages in the social network is under way. This led to the emergence of a new and specific type of media content on the social network.

Based on the analysis of the communication essence of the social network, it can be concluded that the social network acts as a universal public platform for the media, which provides an opportunity for informal communication and for official communications.

Social networks have functions characteristic of mass communication media: communicative, image, social, informational, entertainment and commercial. Note that the social network has become a tool for advertising and PR. He opened up new techniques and methods for users and advertisers as a promotion.

Today, social networks have become part of the toolkit for the full-fledged work of media journalists with the following factors: distribution of the journalist's personal content; increased immersion in events; the social network helps to improve the professional skills of media workers.

\section{REFERENCE LIST}

1. Atyagina, A. P. (2014) Twitter as a new discursive practice / A. P. Atyagina // Abstract of the thesis for the degree of candidate of philological sciences, specialty 10.02.01 - Russian language. - Omsk, 2014. $22 \mathrm{p}$.

2. Butyrina, E. A. (2019) Media promotion in social networks: new tools // Russian science in the modern world. - M.: LLC "Actuality. RF", 2019. - P. 175-176.

3. Vakku, G.V., Klimkina, A.S. (2020) The use of new technologies in online publications (for example, "Meduza") // High technologies and innovations in science: a collection of selected articles of the International Scientific Conference. - SPb.: State Research Institute "National Development", 2020. P. 20-23.

4. Gazizova, RI (2016) Social networks as a platform for creating media content of the mass media of the Republic of Tatarstan. RI Gazizova // Philological sciences. Questions of theory and practice. Tambov: Publishing house "Gramota", 2016. - No. 7 (6199). - P. 90-93.

5. Gradyushko, A.A. (2012)Social media as a tool of modern Internet journalism. / A. A. Gradyushko // Bulletin of the BSU. Ser. 4. Philology. Journalism. Pedagogy: Scientific and theoretical journal of the Belarusian State University. Minsk, - 2012. - No. 2. - P. 69-73.

6. Grimov, O. A. (2014) Sociocultural practices of a person in social networks. / O. A. Grimov // Dis. ... sociol. Sciences: 22.00.06 - sociology of culture. - Kursk, 2014 . - 92 p.

7. Gubanov, DA, Novikov, DA, Chkhartivshili, AG (2009) Models of influence in social networks (review). / D.A. Gubanov // Management of large systems. - 2009. - Issue. 27. - P. 205.

8. Kornysheva, P.E. (2020)Features of the promotion of online media in social networks "VKontakte" and instagram // Discourse of modern media in the perspective of theory, social practice and education. Proceedings of the international scientific and practical conference. - Belgorod, 2020. - P. 125-130.

9. Kuzmina, N.A. (2011) Modern media text: a tutorial. Omsk: Polygraphic center "Tatiana". - 414 p.

10. Morozova, T. A. (2010) Image of the city as the basis for its promotion. / T. A. Morozova // Bulletin of the Adyghe State University. Series 2: Philology and art history. Maykop, - 2010. - No. 1. - P. 73-77. 
11. Official website «Timchenko Galina Promotion of media in social networks». - URL: http://marketing.by/mnenie/prodvizhenie-media-v-sotssetyakh-12-sovetov-ot-glavreda-meduza.

12. Frolova, I.T. (2014) Philosophical Dictionary. // Ed. I. T. Frolova. - 7th ed. - M.: Publishing house "Politizdat", 2014. - 720 p.

13. Ushkin, S. G. (2015) Influence of virtual social networks on protest activity in Russian society. / S. G. Ushkin // Abstract of the dissertation for the degree of candidate of sociological sciences, specialty 22.00.04 - Social structure, social institutions and processes. Saransk, 2015. - 25 p.

14. Official website "Academician". - URL: http://marketing.academic.ru/.

15. Official website "Mediakop". - URL: http://www.mediascope.ru/node.

16. Official website "How the media work with social networks: a detailed guide to promotion-2019". - URL: http:// spark.ru/startup/illuminator/blog/47761/kak-smi-rabotat-s-sotssetyami-podrobnoe-rukovodstvopo-prodvizheniyu.

17. Official website "How simple ru." - URL: http://www.kakprosto.ru/kak-877440-chto-takoe-prodvizhenie-vmarketinge.

\section{Authors}

1. Vakku Grigory Vladislavovich* Corresponding Author - candidate of philological Sciences, associate Professor, associate Professor of the Department of journalism and editorial technology at Moscow state University of Humanitie Build. 49, 401, Losinoostrovskaya str. Moscow, 107150, Russia; e-mail: vakku2006@rambler.ru

ORCID 0000-0001-7676-8962; SPIN-код: 3886-4740; AuthorID: 284494

2. Sasim Anna Viktorovna-candidate of philosophy, associate Professor of the Department of advertising and public relations fgbvou VO "Academy of civil protection EMERCOM of Russia", 141435, Moscow region, Khimki, MD. Novogorsk, FGBVOU VO "Academy of civil protection of EMERCOM of Russia", e-mail: anna-sasim@mail.ru

SPIN-code: 4082-4599, AuthorID: 703082

3. Stepanova Svetlana Evgenievna - candidate of philosophy, associate Professor, Department of economics, management and law, "Chuvash state pedagogical University I. Y. Yakovleva», 428000, Chuvash Republic, Cheboksary, ul. K. Marx, 38. e-mail: clers@mail.ru

SPIN-код: 9615-5690, AuthorID: 443187 